tral government intervention is relatively limited, excessive local government intervention may also hinder institutional innovation. Since the municipal government plays a lesser role in the management of WIAS, it will be interesting to see how Westlake University develops. In other words, these young "startups" require the test of time.

DOI: http://dx.doi.org/10.60I7/ihe.20I7.9I.10042

\section{NEW PUBLICATIONS FROM CIHE}

Elena Denisova-Schmidt. The Challenges of Academic Integrity in Higher Education: Current Trends and Prospects, published in 2017. $\mathrm{CIHE}$ Perspectives 5 addresses the issue of ethics and values in international higher education, an increasing concern in an area of massification, privatization, and globalization in higher education. http://www.bc.edu/content/dam/files/research_sites/ cihe/pubs/ClHE\%2OPerspective/Perspectives\%20No\%205\%2O June $\% 2013 \% 2$ C\%202017\%20No\%20cropsFINAL.pdf.

Ayenachew A. Woldegiyorgis, Laura E. Rumbley, and Hans de Wit, eds. The Boston College Center for International Higher Education, Year in Review, 2016-2017, published in July, 2017. CIHE Perspectives 6 presents a collection of articles-new or recently published-from the Center's graduate students, research fellows, visiting scholars, and faculty. http://www.bc.edu/content/dam/ files/research_sites/cihe/pdf/Perspectives\%20No\%206\%20 Yearbook\%207-27.pdf.

Georgiana Mihut, Philip G. Altbach, and Hans de Wit, eds. Understanding Global Higher Education, Insights from Key Global Publications, published in 2017. This issue of the Global Perspectives on Higher Education series is the first book from a collaboration between CIHE's IHE and University World News, bringing together some of the most relevant articles over the past five years on topics of lasting interest. https://www.sensepublishers.com/ catalogs/bookseries/global-perspectives-on-higher-education/ understanding-global-higher-education. The second book by the same editors is: Understanding Higher Education Internationalization, Insights from Key Global Publications, https://www.sensepublishers.com/catalogs/bookseries/global-perspectives-on-highereducation/understanding-higher-education-internationalization.

Philip G. Altbach, Liz Reisberg, and Hans de Wit, eds. Responding to Massification, Differentiation in Postsecondary Education Worldwide, published in 2017. Having first appeared as a report published by the Körber Foundation, the exploration of how postsecondary education can be organized coherently to meet society's needs is presented in this issue of the Global Perspectives on Higher Education series. https://www.sensepublishers.com/ catalogs/bookseries/global-perspectives-on-higher-education/ responding-to-massification/.

$\mathrm{CIHE}$ is grateful for the multiyear support for International Higher Education that has been provided by the Carnegie Corporation of New York, in particular in relation to coverage of higher education in Africa. 


\section{NEW PUBLICATIONS}

(Editor's note: IHE no longer publishes short book summaries, but rather provides a more comprehensive listing of new books that will be of interest to a higher education audience. We welcome suggestions from readers for books on higher education published especially outside of the United States and United Kingdom. This list was compiled by Edward Choi, graduate assistant at the Center.)

Attebery, Brian, John Gribas, and Mark K. McBeth, eds. Narrative, Identity, and Academic Community in Higher Education. New York, NY: Taylor \& Francis, 2017. 218 pp. \$16o (hb). Website: www.routledge.com.

Banks, James A., ed. Citizenship Education and Global Migration, Implications for Theory, Research, and Teaching. Washington, DC: American Educational Research Association, 2017. 572 pp. \$9o (hb). Website: www.aera.net/ publications.

Deardorff, Darla K., and Lily A. Arasaratnam-Smith, eds. Intercultural Competence in Higher Education-International Approaches, Assessment, and Application. Abington, UK: Routledge, 2017. 312 pp. \$38.95 (pb). Website: www.routledge.com.
Kumar, C. Raj, ed. The Future of Indian Universities: Comparative and International Perspectives. New Delhi: Oxford University Press, 2017. 482 pp. INR 1,495 (hb). Website: global.oup.com.

McMahon, Walter W. Higher Learning, Greater Good: The Private and Social Benefits of Higher Education. Baltimore, Johns Hopkins University Press, 2016. 415 pp. \$22.95 (pb). Website: jhupbookspress.jhu.edu.

Ndlovu, Musawenkosi W. \#Feesmustfall and Youth Mobilisation in South Africa: Reform or Revolution? New York, NY: Taylor \& Francis, 2017. 164 pp. $\$ 140$ (hb). Website: www.routledge. com.

Paige, Susan Mary, et al. The Learning Community Experience in Higher Education: High-Impact Practice for Student Retention. New York, NY: Taylor \& Francis, 2017. 132 pp. \$149.95 (hb). Website: www.routledge.com.

Preece, Julia. University Community Engagement and Lifelong Learning: The Porous University. New York, NY: Palgrave Macmillan, 2017. 214 pp. $€$ 96.29 (hb). Website: www.palgrave. com.

Robertson, Susan L., Kris Olds, Roger Dale, and Que Anh Dang, eds. Global Regionalisms and Higher Education Projects, Processes, Politics. Chelten- ham, UK: Edward Elgar, 2016. 336 pp. $\$ 130.50$ (hb). Website: www.e-elgar. com.

Teferra, D., ed. Flagship Universities in Africa. New York, NY: Palgrave Macmillan, 2017. 535 pp. $€$ 109,99 (hb). Website: www.springer.com.

Troschitz, Robert. Higher Education and the Student: From Welfare State to Neoliberalism. New York, NY: Taylor \& Francis, 2017. 236 pp. \$150 (hb). Website: www.routledge.com.

Whitchurch, Celia, and George Gordon. Reconstructing Relationships in Higher Education: Challenging Agendas. Abington, UK: Routledge, 2017. 192 pp. \$48.95 (pb). Website: www. routledge.com.

Yeravdekar, Vidya Rajiv and Gauri Tiwari. Internationalization of Higher Education in India. New Delhi: Sage, 2016. 284 pp. \$6o (hb). Website: www.us.sagepub.com.

Zwaan, Bert. Higher Education in 2014. A Global Approach. Amsterdam, Netherlands: Amsterdam University Press, 2017. 256 pp. $€ 19.95$ (hb). Website: en.aup.nl. 